\title{
REGULASI WAKAF DI INDONESIA PASCA KEMERDEKAAN DITINJAU DARI STATUTE APPROACH
}

\author{
Sudirman \\ Fakultas Syariah UIN Maulana Malik Ibrahim Malang \\ sudirmansyariah@gmail.com
}

\begin{abstract}
This Article focusing on wakaf regulation in Indonesia after its independence day. The research used statute approach, it also used regulation No. 5 Year 1960 and regulation No. 41 Year 2004 as its primary legal source. In analyzing data it used three legal basis; Lex Superior Derogat Legi Inferiori, Lex Specialis Derogat Legi Generali, and Lex Posterior Derogat Legi Priori. Firstly, it concludes that the background of regulating the wakaf regulation in Indonesia was conducted because of public needs to a special regulation which can rules wakaf and its legal contemporary development. Secondly, the comparison of wakaf regulations regulated from post-independence until reformation era explained that in the first concept of wakaf and its implementation opportunity was realized in The Reg. 5/1960. But the concept of Nâdzir firstly introduced in Gov. Regulation No. 28/1977 and established by the Indonesian compilation of Islamic Law. Thirdly, penal punishment changes, and according to statute approach analysis using those three legal basis, the Reg. 41/2004 is the most updated wakaf regulation in Indonesia.
\end{abstract}

Tulisan ini difokuskan pada penelitian regulasi wakaf di Indonesia pasca kemerdekaan. Penelitian ini menggunakan pendekatan perundangan-undangan (statute approach). Bahan hukum primer yang digunakan adalah Undang-Undang Nomor 5 Tahun 1960 dan Undang-Undang Nomor 41 Tahun 2004. Penelitian ini dalam analisisnya menggunakan tiga asas, yakni asas Lex Superior Derogat Legi Inferiori, asas Lex Specialis Derogat Legi Generali, dan asas Lex Posterior Derogat Legi Priori. Kesimpulan penelitian ini menemukan bahwa latar belakang munculnya berbagai peraturan wakaf di Indonesia pasca kemerdekaan sarat dengan tuntutan perlunya regulasi khusus yang mengatur tentang wakaf serta reaksi dari perkembangan hukum wakaf kontemporer. 2) Perbandingan regulasi wakaf pasca kemerdekaan hingga era reformasi menunjukkan bahwa dalam hal konsep wakaf, UU 5/1960 telah memberikan peluang terjadinya wakaf di Indonesia. Dalam hal nâzhir, konsep awal sudah diperkenalkan dalam PP 28/1977 dan dikuatkan oleh KHI. Terakhir, aturan pidana dari waktu ke waktu mengalami perubahan. 3) Regulasi ditinjau dari Statute Approach dapat dianalisis dengan menggunakan tiga asas hukum menyimpulkan UU 41/2004 menjadi aturan wakaf paling mutakhir dan puncak regulasi wakaf di Indonesia.

Kata Kunci: Konsep wakaf, nâzhir, ketentuan pidana, statute approach

Jejak sejarah regulasi wakaf di Indonesia dapat dimulai sejak masa penjajahan. Hal ini dapat dibuktikan dengan lahirnya beberapa peraturan tentang wakaf di era pemerintah Hindia Belanda. Menurut Djunaidi, tidak kurang dari empat surat edaran tentang wakaf yang diluncurkan. Di antaranya adalah Surat
Edaran Sekretaris Governemen pertama tanggal 31 Januari 1905, Nomor 435 yang tertuang dalam Bijblad 1905 No. 6196 tentang Toezicht op den bouw van Muhammadaansche Bedehuizen. Surat ini menunjukkan bahwa pemerintah Kolonial tidak melarang praktik wakaf yang dilakukan oleh umat Islam di 
wilayah Jawa dan Madura demi menjalankan ajaran agamanya asalkan tempat ibadah tersebut diperuntukkan bagi kepentingan umum. ${ }^{1}$ Surat-surat edaran lainnya memiliki semangat serupa untuk menertibkan administrasi tanah wakaf di bawah naungan bupati atau pejabat yang berwenang.

Potensi wakaf di Indonesia hingga kini cukup menggembirakan. Menurut data Direktorat Urusan Agama Islam, pada tahun 1999, jumlah tanah wakaf di seluruh Indonesia tercatat $1.477 .111 .015 \mathrm{~m}^{2}$ yang terdiri atas 349.296 lokasi. Pada tahun 2012, luas tanah wakaf di Indonesia meningkat lebih dari dua kali lipat hingga mencapai 3.492.045.373,754 $\mathrm{m}^{2}$ di 420.003 titik. $^{2}$

Perkembangan terakhir di atas tidak lepas dari pergeseran regulasi di Indonesia, terutama setelah kemerdekaan. Jika dihitung secara cermat, regulasi tentang wakaf pasca kemerdekaan dapat dimulai sejak lahirnya Undang-Undang Pokok Agraria Nomor 5 Tahun 1960. Dalam Undang-Undang tersebut dinyatakan bahwa tanah wakaf akan diatur secara khusus dalam Peraturan Pemerintah. Sayangnya, peraturan yang diamanahkan tersebut tidak kunjung lahir. Baru setelah 17 tahun kemudian, disahkanlah Peraturan Pemerintah No 28 Tahun 1977 yang membahas secara rinci tentang wakaf tanah milik.

Menyadari perkembangan wakaf yang signifikan, penelitian ini difokuskan pada penelitian regulasi wakaf di Indonesia pasca kemerdekaan. Topik ini diambil dengan maksud untuk menggambarkan perkembangan regulasi dari awal kemerdekaan hingga era reformasi yang ditandai dengan lahirnya Undang-Undang No 41 Tahun 2004 tentang Wakaf yang cukup revolusioner. Sejumlah peraturan aplikatif yang merupakan terjemahan administratif dari Undang-Undang ini juga dipaparkan secara detail dalam penelitian ini.

Untuk memberikan analisis yang tajam, penelitian ini menyajikan perbandingan antara satu peraturan dengan peraturan lain yang dimiliki Indonesia setelah kemerdekaan.

\footnotetext{
${ }^{1}$ Achmad Djunaidi, dkk., Perkembangan Pengelolaan Wakaf di Indonesia, Jakarta: Direktorat Pemberdayaan Wakaf, 2006: 15-16.

${ }^{2}$ http://bimasislam.kemenag.go.id/informasi/berita/3 5-berita/660-luas-tanah-wakaf-di-indonesia3492045373754-m2.html diakses 27 Agustus 2013.
}

Sudirman, Regulasi Wakaf di Indonesia...|

Perbandingan ini meliputi penyajian persamaan dan perbedaan dari tiap-tiap peraturan perudangan-undangan yang kemudian dianalisis dengan teori statute approach Peter Mahmud Marzuki. Dipilihnya teori pendekatan perundangan-undangan sebagai alat analisis karena teori ini dinilai tepat untuk mendudukkan setiap aturan hukum secara sejajar dan seimbang sehingga dapat diperoleh gambaran keberanjakan hukum dari masa ke masa, khususnya pasca kemerdekaan.

\section{Konsep Wakaf}

Wakaf secara bahasa berasal dari bahasa

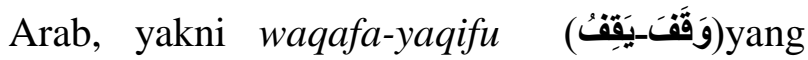
artinya berhenti, lawan dari kata istamarra (إسنتَنَرَّرَ). Wehr mengartikan waqafa sebagai to come to a standstill atau to come to stop. ${ }^{4}$ Kata wakaf sering disamakan dengan al-

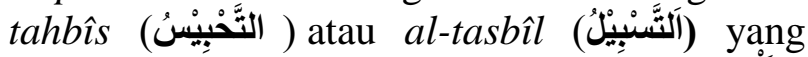

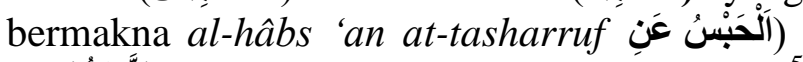
(التََّرَُْفِ), yakni mencegah dari mengelola. ${ }^{5}$ Dalam literatur bahasa Inggris, wakaf biasa disebut sebagai endowment, endowment fund, atau unalienable property. ${ }^{6}$

Adapun secara istilah, wakaf menurut Abû Hanîfah dalam al-Hafsakî ${ }^{7}$ adalah

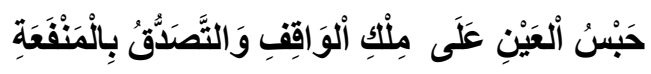

yakni menahan harta di bawah naungan pemiliknya disertai pemberian manfaat sebagai sedekah. Kemudian, menurut az-Zuhailî, ${ }^{8}$ wakaf adalah menahan harta yang memungkinkan untuk mengambil manfaat dengan tetapnya harta tersebut serta memutus pengelolaan dari wâkif dan selainnya dengan tujuan mendekatkan diri kepada Allah dengan redaksi sebagai berikut.

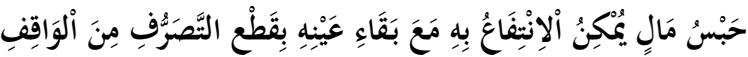

$$
\begin{aligned}
& \text { وَغَغْرِهِ تَقَقَبًْا إِلىَ اللهِ }
\end{aligned}
$$

\footnotetext{
${ }^{3}$ Ahmad Warson, al-Munawwir, Kamus ArabIndonesia, (t.tp.: t.p., 1984), h.1683.

${ }^{4}$ Hans Wehr, Arabic-English Dictionary, the Hans Wehr Dictionary of Modern Written Arabic, (Urbana: Spoken Language Services, 1994), h. 1280

${ }^{5}$ Wahbah az-Zuhailî, al-Fiqh al-Islâmî wa Adillatuh, (Beirut: Dâr al-Fikr, t.th.), h. 7599.

${ }^{6}$ Wehr, Arabic-English, p. 1280

${ }^{7}$ Alauddin Muhammad bin 'Alî al-Hafsakî, ad-Dur al-Mukhtär, (t.tp.: t.p., t.th./IV), h. 532.

${ }^{8}$ Wahbah az-Zuhailî, al-Fiqh, h. 7601.
} 
Selain dua definisi di atas, menurut alKabisi, ${ }^{9}$ definisi yang lebih singkat namun padat (jâmi' mâni') adalah definisi Ibn Qudâmah $^{10}$ yang mengadopsi langsung dari potongan hadis Rasulullah, yang berbunyi:

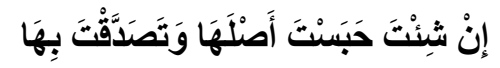

Artinya: menahan asal dan mengalirkan hasilnya. Hadis tersebut secara jelas dimuat antara lain dalam Sunan at-Turmudzî. ${ }^{11}$

Dari beberapa definisi wakaf di atas, dapat disimpulkan bahwa intisari wakaf adalah menjaga dan mengelola pokok harta yang telah diserahkan untuk kepentingan agama dan menyalurkan hasilnya untuk kemaslahatan umat. Wakaf bertujuan untuk memberikan manfaat atau faedah harta yang diwakafkan kepada orang yang berhak dan dipergunakan sesuai dengan ajaran Islam. ${ }^{12}$

\section{Teori Statute Approach versi Peter Mahmud Marzuki}

Dalam bukunya yang populer berjudul "Penelitian Hukum", Marzuki menjelaskan tentang beberapa pendekatan dalam penelitian hukum. Dengan pendekatan tersebut, peneliti dapat memperoleh informasi dari berbagai aspek mengenai isu yang sedang diteliti. Pendekatan-pendekatan yang dapat digunakan terdiri atas lima macam, yaitu pendekatan undang-undang (statute approach), pendekatan kasus (case approach), pendekatan historis (historical approach), pendekatan komparatif

9 Muhammad Abid Abdullah al-Kabisi, 2004, Hukum Wakaf, diterjemahkan oleh Ahrul Sani Fathurrohman (et.al.), Jakarta, IIMaN Press, 2004, h. 61.

${ }^{10}$ ‘ Abd ar-Rahmân bin Abû 'Umar ibn Qudâmah, asy-Syarh al-Kabîr, t.tp.: t.p., t.th./VI), h. 187.

11 Muhammad bin 'Îsâ at-Turmudzi, Sunan atTurmudzi, Kairo: Mauqi“ Wizârah al-Auqâf alMishriyyah, t.th./V), h. 388.

12 Dalam buku Agar Harta Berkah dan Bertambah, Hafidhuddin (2007) mengatakan bahwa sifat harta berkah ada tiga hal, yakni harta "taqarrub", harta manfaat, dan harta berkecukupan. Maksud harta "taqarrub" adalah harta tersebut jika dimiliki oleh seseorang yang cara yang benar akan semakin mendekatkan dirinya kepada sang pemilik harta hakiki, yakni Allah SWT. Harta manfaat maksudnya bahwa harta yang dimiliki oleh seorang Muslim haruslah memberikan kemanfaatan tidak hanya untuk diri sendiri namun juga untuk orang lain. Adapun harta berkecukupan maksudnya adalah harta yang dimiliki seseorang harus dapat membuatnya merasa cukup. (comparative approach), dan pendekatan konseptual (conceptual approach).

Pendekatan undang-undang dilakukan dengan menelaah semua undang-undang dan regulasi yang bersangkut paut dengan isu hukum yang sedang ditangani. Bagi penelitian untuk kegiatan praktis, pendekatan undangundang ini akan membuka kesempatan bagi peneliti untuk mempelajari ada tidaknya konsistensi dan kesesuaian antara suatu undang-undang dengan undang-undang lainnya atau antara undang-undang dan undang-undang dasar atau natar undang-undang regulasi dan undang-undang. Hasil dari telaah tersebutmerupakan suatu argumen untuk memecahkan isu yang dihadapi. Bagi penelitian untuk kegiatan akademis, peneliti perlu mencari ratio legis dan dasar ontologis lahirnya undang-undang tersebut. Dengan mempelajari ratio legis dan dasar ontologis suatu undang-undang, peneliti sebenarnya mampu menangkap kandungan filosofi yang ada di belakang undang-undang itu. Memahami kandungan filosofi yang ada di belakang undang-undang itu, peneliti tersebut akan dapat menyimpulkan mengenai ada tidaknya benturan filosofis antara undang-undang dengan isu yang dihadapi. ${ }^{13}$

Kecuali penelitian dalam ruang lingkup hukum adat, penelitian hukum dalam level dogmatik hukum atau penelitian untuk keperluan praktik hukum tidak dapat melepaskan diri dari pendekatan perundangundangan. Penelitian untuk karya akademik dari level teori atau filsafat hukum dapat saja tidak menggunakan pendekatan perundangundangan karena mungkin belum ada ketentuan perundang-undangan yang dijadikan referensi dalam memecahkan isu hukum yang diajukan. $^{14}$

Dalam metode pendekatan perundangundangan, peneliti perlu memahami hierarki dan asas-asas dalam peraturan perundangundangan. Menurut pasal 1 angka 2 UU Nomor 10 Tahun 2004, peraturan perundang-undangan adalah peraturan tertulis yang dibentuk oleh lembaga negara atau pejabat yang berwenang dan mengikat secara umum. Dari pengertian tersebut, secara singkat dapat dikatakan bahwa yang dimaksud sebagai statute berupa legislasi

\footnotetext{
${ }^{13}$ Peter, Penelitian, h. 93-94

${ }^{14}$ Peter, Penelitian, h. 96-97.
} 
dan regulasi. Jika demikian, pendekatan peraturan perundang-undangan adalah pendekatan dengan menggunakan legislasi dan regulasi. Produk yang merupakan decree, yaitu suatu keputusan yang diterbitkan oleh pejabat administrasi yang bersifat konkret dan khusus, misalnya keputusan presiden, keputusan menteri, keputusan bupati, atau keputusan suatu badan tertentu tidak dapat digunakan dalam pendekatan perundang-undangan.

Pemahaman tersebut mempunyai arti penting dalam memahami asas lex superior derogat legi inferiori. Menurut asas ini, apablia terjadi pertentangan antara peraturan perundangan-undangan yang secara hierarkis lebih rendah dengan yang lebih tinggi, peraturan perundang-undangan yang hierarkinya lebih rendah tersebut harus disisihkan.

Di samping asas lex superior derogat legi inferiori, dalam melakukan pendekatan peraturan perundang-undangan, peneliti juga bisa memahami asas lex specialis derogat legi generali. Asas ini merujuk kepada dua peraturan perundang-undangan yang secara hierarkis mempunyai kedudukan yang sama. Akan tetapi, ruang lingkup materi muatan antara kedua peraturan perundang-undangan itu tidak sama, yaitu satu merupakan pengaturan secara khusus dari yang lain. ${ }^{15}$

Asas peraturan perundang-undangan berikutnya adalah lex posterior derogat legi priori. Artinya, peraturan perundang-undangan yang belakangan menyisihkan peraturan perundang-undangan yang terdahulu. Asas ini berkaitan dengan dua peraturan perundangundangan yang mengatur masalah yang sama, mislanya UU No 14 Tahun 1970 dan UU No 4 Thaun 2004 tentang kekuasaan kehakiman. Sebagaimana yang terjadi ada asas lex specialis derogat legi generali, penggunaan asas ini mensyaratkan bahwa yang diperhadapkan adalah dua peraturan perundang-undangan dalam hierarki yang sama.

\section{Perkembangan Regulasi Wakaf di Indonesia}

Perkembangan regulasi wakaf dapat dilihat dari karakter wakaf di Indonesia. Wakaf yang dipraktikkan di berbagai negara termasuk Indonesia memiliki karakter tersendiri, meskipun bila ditelusuri lebih mendalam

\footnotetext{
${ }^{15}$ Peter, Penelitian, h. 98-99.
}

memiliki kesamaan tujuan. Ada beberapa istilah khas Indonesia tentang wakaf ini. Di Banten, dikenal istilah "Huma Serang" yang merupakan ladang-ladang yang dikelola bersama-sama dan hasilnya pun dapat digunakan untuk kepentingan bersama. Di Lombok, ada istilah "Tanah Pareman" yang merupakan tanah negara yang dibebaskan dari pajak "Landrette". Hasil tanah itu diserahkan ke desa-desa, subak, dan Candi untuk digunakan kepentingan umum. Selain itu, di Jawa Timur, ada istilah tanah "Perdikan" yang merupakan tanah pemberian raja kepada seseorang atau kelompok orang yang berjasa. Tanah ini mempunyai kemiripan dengan wakaf ahli (wakaf untuk keluarga) dari segi fungsi dan pemanfaatannya. Tanah perdikan pun tidak boleh dijualbelikan. ${ }^{16}$ Dari sini dapat disimpulkan bahwa wakaf di Indonesia memiliki corak khas sesuai dengan daerahnya.

\section{Masa Pasca Kemerdekaan RI}

Dengan adanya Proklamasi Kemerdekaan RI tanggal 17 Agustus 1945, peraturanperaturan yang dikeluarkan pada masa penjajahan dinyatakan masih berlaku kecuali bila sudah ada aturan barunya. Hal ini sesuai dengan pasal peralihan Undang-Undang Dasar 1945. Dalam hal wakaf, Departemen Agama telah mengeluarkan petunjuk tentang wakaf pada tanggal 22 Desember 1953. Perwakafan dijadikan salah satu wewenang dari Jabatan Urusan Agama, yakni bagian D atau ibadah sosial. $^{17}$

Surat Edaran Nomor 5/D/1956 tentang Prosedur Perwakafan Tanah dikeluarkan pada tanggal 8 Oktober 1956. Surat ini menindaklanjuti peraturan sebelumnya yang dianggap belum memberikan kepastian hukum di bidang wakaf.

\section{Regulasi Wakaf}

Selanjutnya, aturan tentang wakaf dijabarkan lebih lanjut di dalam UndangUndang No 5 Tahun 1960 tentang Agraria. Pada pasal 49 ditemukan ketentuan sebagai berikut.

\section{1) Untuk keperluan peribadatan dan} keperluan suci lainnya sebagai

\footnotetext{
${ }^{16}$ Djunaidi dkk., Perkembangan, h. 13.

${ }^{17}$ Djunaidi dkk., Perkembangan, h. 16.
} 
194 | de Jure, Jurnal Syariah dan Hukum, Volume 6 Nomor 2, Desember 2014, hlm. 190-203

dimaksud dalam pasal 14 dapat diberikan tanah yang dikuasai langsung oleh negara dengan hak pakai.

2) Perwakafan tanah milik dilindungi dan diatur dengan peraturan pemerintah.

Pasal ini memberikan penegasan bahwa pemerintah harus memberikan aturan jelas tentang wakaf dalam bentuk Peraturan Pemerintah (PP). Sayangnya PP yang ditunggu-tunggu itu baru lahir 17 tahun kemudian setelah disahkannya Peraturan Pemerintah Nomor 28 Tahun 1977 pada tanggal 17 Mei 1977. Dengan demikian, selama rentang waktu tersebut, peraturan yang dipakai tentunya adalah peraturan yang sudah berlaku sebelumnya. ${ }^{18}$

Beberapa peraturan telah disesuaikan dengan disahkannya PP No 28 Tahun 1977. Di antaranya adalah adanya definisi wakaf yang berbunyi:

\section{wakaf adalah suatu lembaga keagamaan yang dapat diperuntukkan sebagai salah satu sarana guna pengembangan kehidupan keagamaan, khususnya bagi umat yang beragama Islam dalam rangka mencapai kesejahteraan spiritual dan material menuju masyarakat adil dan makmur berdasarkan Pancasila.}

Peraturan yang ada sebelum lahirnya PP ini dianggap belum memenuhi kebutuhan tentang cara-cara perwakafan yang benar dan membuka kemungkinan timbulnya berbagai masalah wakaf. Oleh sebab itu, pemberlakuan PP ini meniscayakan ketidakberlakukan peraturanperaturan sebelumnya, khususnya yang bertentangan dengan PP tersebut. Hal-hal yang belum diatur dalam PP ini akan diatur lebih lanjut oleh Menteri Agama dan Menteri Dalam Negeri sesuai dengan tugas masing-masing.

Dengan adanya PP No 28 Tahun 1977, umat Islam mendapat dukungan legal formal dan terperinci mengenai wakaf. PP ini tentu saja berlaku lebih luas tidak hanya wilayah Jawa dan Madura melainkan seluruh wilayah Negara Kesatuan Republik Indonesia. Umat Islam di seluruh penjuru tanah air akan menundukkan diri kepada PP ini.
Perbandingan Regulasi Wakaf di Indonesia

Pada bagian ini diuraikan tentang perbandingan beberapa konsep penting antara beberpa regulasi wakaf. Di antaranya adalah konsep wakaf, konsep nâzhir, dan sanksi pidana.

\section{Konsep Wakaf}

Undang-Undang Nomor 5 Tahun 1960 (berikutnya disingkat UU No 5/1960)

Mengawali pembahasan ini, peraturan wakaf yang menjadi landasan wakaf di Indonesia pasca kemerdekaan adalah UndangUndang No 5 Tahun 1960 tentang Agraria. Pada pasal 49 ditemukan ketentuan sebagai berikut.

1) Untuk keperluan peribadatan dan keperluan suci lainnya sebagai dimaksud dalam pasal 14 dapat diberikan tanah yang dikuasai langsung oleh negara dengan hak pakai.

2) Perwakafan tanah milik dilindungi dan diatur dengan peraturan pemerintah.

Pasal ini menegaskan bahwa tanah yang digunakan untuk kepentingan peribadatan, seperti lokasi pembangunan masjid dan madrasah, mendapat pengakuan secara resmi. Jenis tanah yang bisa dimanfaatkan untuk keperluan tersebut ada dua macam: yakni tanah hak pakai dan tanah hak milik. Tanah hak pakai berasal dari tanah yang dikuasai negara sedangkan tanah hak milik berasal dari tanah pribadi. Untuk menjalankan wakaf, UndangUndang ini mengamanatkan untuk lahirnya peraturan pemerintah yang mengatur tentang wakaf tanah milik.

\section{Peraturan Pemerintah Nomor 28 Tahun 1977 (berikutnya disingkat PP No 28/1977)}

Setelah menunggu sekitar 17 tahun, peraturan pemerintah yang dinantikan baru disahkan tanggal 17 Mei 1977. Peraturan itu adalah Peraturan Pemerintah Nomor 28 Tahun 1977 tentang Perwakafan Hak Milik. PP ini secara resmi mengganti Bijblad-bijblad Nomor 6196 Tahun 1905, Nomor 12573 Tahun 1931, Nomor 13390 Tahun 1934, dan Nomor 13480 Tahun 1935 beserta ketentuan pelaksanaannya.

\footnotetext{
${ }^{18}$ Djunaidi dkk., Perkembangan, h. 17.
} 
PP ini terdiri dari VII bab dan 18 Pasal. Bab I adalah Ketentuan Umum. Bab ini berisi satu pasal. Pasal ini menjelaskan definisi wakaf, wâkif, ikrar, dan nâzhir. Pada pasal 1 ayat (1) memberikan definisi wakaf sebagai berikut:

Wakaf adalah perbuatan hukum
seseorang atau badan hukum yang
memisahkan sebagian harta kekayaannya
yang berupa tanah milik dan
melembagakannya untuk selama-lamanya
untuk kepentingan peribadatan atau
keperluan umum lainnya sesuai dengan
ajaran agama Islam.

Definisi ini merupakan terobosan baru yang menegaskan bahwa wakaf dapat dilakukan baik perorangan maupun badan hukum dengan memberikan tanah miliknya untuk kepentingan keagamaan. Tanah wakaf yang sudah diserahkan tidak dapat ditarik kembali karena peraturan ini menegaskan wakaf untuk selamalamanya.

\section{Kompilasi Hukum Islam (berikutnya disingkat KHI)}

Dalam KHI pasal 215 ayat (1), wakaf didefinisikan sebagai berikut.

Wakaf adalah perbuatan hukum seseorang atau kelompok orang atau badan hukum yang memisahkan sebagian dari benda miliknya dan melembagakannya untuk selama-lamanya guna kepentingan ibadat atau keperluan umum lainnya sesuai dengan ajaran Islam.

Definisi wakaf dalam KHI tidak jauh berbeda dengan definisi wakaf dalam PP 28 Tahun 1977. Hal ini disebabkan oleh posisi KHI dalam tata urutan perundang-undangan yang memang lebih rendah dari PP. Meskipun begitu, ada sedikit perbedaan redaksi definisi wakaf antara PP dan KHI. Perbedaan itu terletak pada frase tambahan "atau kelompok orang", frase "sebagian dari benda miliknya" menggantikan "harta kekayaannya yang berupa tanah milik", dan frase " guna kepentingan ibadat" menggantikan "untuk kepentingan peribadatan". Secara substansi kedua definisi memiliki makna yang sama. Hanya pada tambahan "atau kelompok orang" dapat memberikan makna bahwa KHI mengakomodasi kemungkinan wakaf yang
Sudirman, Regulasi Wakaf di Indonesia...| 195

dilakukan oleh beberapa orang dalam satu kelompok.

\section{Undang-Undang Nomor 41 Tahun 2004 (berikutnya disingkat UU No 4/2004)}

Dalam UU No 41/2004 pasal 1 ayat (1) disebutkan bahwa

Wakaf adalah perbuatan hukum wâkif
untuk memisahkan dan/atau menyerahkan
sebagian harta benda miliknya untuk
dimanfaatkan selamanya atau untuk
jangka waktu tertentu sesuai dengan
kepentingannya guna keperluan ibadat
dan/atau kesejahteraan umum menurut
syariah.

Definisi yang tercantum dalam UU ini memuat frase yang belum pernah muncul sebelumnya, yakni "untuk jangka waktu tertentu". Frase ini menunjukkan perubahan yang signifikan dalam fiqh wakaf Indonesia. Sebelumnya, wakaf selalu identik dengan penyerahan harta untuk selama-lamanya, namun dalam fiqh terbaru Indonesia, wakaf bisa berjangka. Artinya, seseorang bisa memberikan hartanya kepada pengelola wakaf untuk dimanfaatkan dalam rentang waktu yang dipersyaratkan, misalnya satu tahun. Setelah berlalu satu tahun, harta tersebut kembali kepada wâkif.

Perubahan cara pandang di atas tidak lepas dari dinamika wakaf yang terjadi dalam fiqh. Dalam fiqh Syafi'i, wakaf adalah penyerahan harta kepada Allah sehingga hak milik manusia berpindah kepada hak milik Allah. Karena bukan lagi milik manusia, maka tidak ada alasan untuk mengembalikan harta itu kepada manusia. Penyerahan harta untuk Allah berlangsung sekali dan tidak dapat ditarik kembali. ${ }^{19}$ Berbeda dengan itu, fiqh Maliki menegaskan bahwa harta yang diwakafkan tidak menghilangkan hak kepemilikan manusia atau wâkif. Harta wakaf memang tidak boleh dimanfaatkan (di-tasharruf-kan) oleh wâkif selama masa wakaf. Namun, bila sudah selesai masanya, wâkif berhak menggunakan harta itu seperti sediakala. ${ }^{20}$ Sejalan dengan fiqh Maliki, fiqh Hanafi menegaskan bahwa wakaf itu seperti pinjam-meminjam. Jika masa

\footnotetext{
${ }^{19}$ Wahbah az-Zuhailî, al-Fiqh al-Islâmî wa Adillatuh, (Beirut: Dâr al-Fikr, t.th.), vol. 8, h. 154-155.

${ }^{20}$ Wahbah az-Zuhailî, al-Fiqh, h. 155-156.
} 
peminjaman telah terlampaui, harta wakaf kembali menjadi milik wâkif. ${ }^{21}$

Dari uraian di atas dapat disimpulkan bahwa definisi wakaf yang tercantum dalam PP 28/1977 dan KHI dipengaruhi oleh fiqh Syafi'i sedangkan definisi wakaf dalam UU 41/2004 dipengaruhi oleh fiqh Maliki dan Hanafi. Dengan demikian, hukum wakaf di Indonesia sangat dinamis seiring dengan perubahan dan tuntutan zaman. Penggunaan fiqh Maliki pada masyarakat yang lebih cenderung pada fiqh Syafi'i menunjukkan kedewasaan umat Islam Indonesia dalam merespon dinamika zaman.

\section{Peraturan Pemerintah Nomor 42 Tahun 2006 (berikutnya disingkat PP 42/ 2006)}

Dalam PP 42/2006 pasal 1 ayat (1), definisi wakaf sama dengan definisi wakaf dalam UU 41/2004.

Wakaf adalah perbuatan hukum wâkif untuk memisahkan dan/atau menyerahkan sebagian harta benda miliknya untuk dimanfaatkan selamanya atau untuk jangka waktu tertentu sesuai dengan kepentingannya guna keperluan ibadah dan/atau kesejahteraan umum menurut syariah.

Hal ini wajar karena posisi PP 42/2006 adalah penjelasan dari UU 41/2004. Jika ada perbedaan, tentunya akan menunjukkan inkonsistensi dalam perundang-undangan Indonesia. Meskipun begitu jika dicermati dari huruf ke huruf, ada perbedaannya kecil antara UU 41/2004 dan PP 42/2006, yakni pada kata ibadah dan ibadat. UU 41/2004 menyebut ibadat sedangkan PP 42/2006 menyebut ibadah. Hal ini bisa saja terjadi karena salah ketik atau proses transliterasi yang tidak tuntas.

Bila dikonfirmasikan ke Kamus Besar Bahasa Indonesia, ternyata kedua istilah tersebut sama-sama diakui meskipun memiliki penekanan yang berbeda. Ibadah diartikan sebagai perbuatan untuk menyatakan bakti kepada Allah yang didasari ketaatan mengerjakan perintah-Nya dan menjauhi larangan-Nya. ${ }^{22}$ Adapun ibadat dimaknai sebagai segala usaha lahir dan batin sesuai dengan perintah Tuhan untuk mendapatkan

\footnotetext{
${ }^{21}$ Wahbah, al-Fiqh, h. 153-154.

${ }^{22}$ http://kbbi.web.id/ibadah, diakses tanggal 5 Oktober 2014.
}

kebahagiaan dan keseimbangan hidup, baik untuk diri sendiri, keluarga, masyarakat maupun terhadap alam semesta. ${ }^{23}$ Dari definisi KKBI, nampak jelas bahwa ibadah lebih dikhususkan kepada ritualitas umat Islam sedangkan ibadat bermakna lebih umum untuk segala jenis agama dan kepercayaan. Dari sini dapat disimpulkan bahwa redaksi PP yang menggunakan kata "ibadah" dapat dimungkinkan untuk memberikan penekanan pemanfaatan wakaf khusus untuk kepentingan umat Islam.

\section{Konsep Nâzhir UU 5/1960}

Dalam UU ini belum ada penjelasan tentang nâzhir.

\section{PP 28/77}

Dalam PP 28/77, konsep nâzhir dijelaskan dalam pasal 1 ayat (4) sebagai berikut.

\section{Nâzhir adalah kelompok orang atau badan hukum yang diserahi tugas pemeliharaan dan pengurusan benda wakaf.}

Dari definisi tersebut dapat dipahami bahwa jenis nâzhir ada dua, yakni nadzhir kelompok orang dan badan hukum. Hal ini akan berbeda dengan perkembangan selanjutnya bahwa selain kedua jenis nâzhir di atas, ada jenis ketiga yakni nâzhir organisasi. Kemudian, tugas utama nâzhir adalah memelihara dan mengurus benda wakaf. Persyaratan menjadi nâzhir diatur dalam pasal 6. Pasal ini menjelaskan persyaratan dua jenis nâzhir. Jika nâzhir kelompok orang, maka syaratnya sebgaai berikut: a) warganegara Republik Indonesia; b) beragama Islam; c) sudah dewasa; d) sehat jasmaniah dan rohaniah; e) tidak berada di bawah pengampuan; f) bertempat tinggal di Kecamatan tempat letaknya tanah yang diwakafkan.

Namun bila berbentuk badan hukum, maka persyaratan yang harus dipenuhi adalah: a) badan hukum Indonesia dan berkedudukan di Indonesia; b) mempunyai perwakilan di kecamatan tempat letaknya tanah yang diwakafkan.

Dari paparan di atas, dapat disimpulkan bahwa persyaratan nâzhir kelompok orang

\footnotetext{
${ }^{23}$ http://kbbi.web.id/ibadat, diakses tanggal 5 Oktober 2014.
} 
lebih banyak daripada nâzhir badan hukum. Hal ini disebabkan karena nâzhir perseorangan melekat pada diri seseorang sehingga unsur personalitas menjadi pertimbangan penting. Adapun nâzhir badan hukum lebih fleksibel dan tidak menekankan pada persyaratan personalitas. Pada poin ini, nâzhir badan hukum nampak lebih mudah dan lebih aman dalam penjagaan benda wakaf karena keterlibatan individu lebih rendah.

Lebih lanjut, tentang kewajiban dan hak-hak nâdzir, pasal 7 dan pasal 8 menjelaskan sebagai berikut. Pasal 7 menyebutkan: (1) Nâdzir berkewajiban untuk mengurus dan mengawasi kekayaan wakaf serta hasilnya menurut ketentuan-ketentuan yang diatur lebih lanjut oleh Menteri Agama sesuai dengan tujuan wakaf; (2) Nâdzir diwajibkan membuat laporan secara berkala atas semua hal yang menyangkut kekayaan wakaf sebagaimana dimaksud dalam ayat (1); (3) Tatacara pembuatan laporan seperti dimaksud dalam ayat (2), diatur lebih lanjut oleh Menteri Agama. Pasal 8 menyebutkan Nâdzir berhak mendapatkan penghasilan dan fasilitas yang besarnya dan macamnya ditentukan lebih lanjut oleh Menteri Agama.

Kedua pasal di atas menjelaskan tentang kewajiban dan hak nâzhir. Kewajiban utama adalah mengawasi dan mengurus benda wakaf yang kemudian dilaporkan secara berkala. Setelah itu, nâzhir baru berhak mendapatkan haknya yang besarnya belum ditentukan.

\section{KHI}

Dalam hal nâzhir, KHI banyak mengadopsi dari PP 28. Termasuk dalam persyaratan nâzhir kelompok orang dan badan hukum serta tugas kewajibannya. Yang sedikit berbeda adalah persoalan hak. Hak nâzhir termaktub dalam pasal 222 yang berbunyi:

Nâzhir berhak mendapatkan penghasilan dan fasilitas yang jenis dan jumlahnya ditentukan berdasarkan kelayakan atas saran Majelis Ulama Kecamatan dan Kantor Urusan Agama Kecamatan setempat.

Kalau dalam PP 28, hak nâzhir menunggu ketentuan menteri agama, namun dalam KHI hak nâzhir didasarkan pada saran majelis ulama keacamatan dan KUA. Dengan demikian, musyawarah antara nâzhir, majelis ulama, dan KUA menentukan besaran hak nâzhir yang layak.

\section{UU 41/2004}

Dalam UU No 41/2004, nâzhir dibahas detail pada pasal 9, 10, 11, dan 12. Dalam pasal 9, jenis nâzhir terbagi dalam tiga kategori, yaitu perseorangan, organisasi,dan badan hukum. Pasal 10 menjelaskan persyaratan nâzhir perseorangan, yakni harus memenuhi syarat sebagai berikut: a) Warga negara Indonesia; b) Beragama Islam; c) Dewasa; d) Amanah; e) Mampu secara jasmani dan rohani; dan f) Tidak terhalang melakukan perbuatan hokum.

Adapun tugasnya dipaparkan dalam pasal 11 dijelaskan bahwa Nâzhir mempunyai tugas sebagai berikut: a) melakukan pengadministrasian harta benda wakaf; b) mengelola dan mengembangkan harta benda wakaf sesuai dengan tujuan, fungsi, dan peruntukannya; c) mengawasi dan melindungi harta benda wakaf; d) melaporkan pelaksanaan tugas kepada Badan Wakaf Indonesia.

Ketika nâzhir sudah melaksanakan kewajibannya, maka ia berhak mendapatkan haknya yang lebih jelas, yaitu 10\%. Hal ini tercantum dalam pasal 12 berikut ini.

\section{Pasal 12}

Dalam melaksanakan tugas sebagaimana dimaksud dalam Pasal 11, Nâzhir dapat menerima imbalan dari hasil bersih atas pengelolaan dan pengembangan harta benda wakaf yang besarnya tidak melebihi $10 \%$ (sepuluh persen).

Hal yang harus digarisbawahi dalam memahami pasal 12 ini adalah bahwa nâzhir akan berhak mendapatkan $10 \%$ setelah memanfaatkan aset wakaf secara produktif. Dengan kata lain, jika nâzhir tidak mampu mengelola harta benda wakaf, maka ia tidak akan pernah mendapatkan bagian apapun karena ia tidak boleh mengambil aset wakaf untuk dirinya. $10 \%$ yang merupakan hak nâzhir diambil dari hasil bersih usahanya. Misalnya, aset wakaf berjumlah 1 milyar, kemudian diputar secara produktif baik dalam sektor keuangan maupun sektor riil dan menghasilnya 100 juta. Maka, dalam kasus ini, nâzhir boleh mengambil haknya maksimal $10 \%$ atau dalam kasus ini maksimal 10 juta. 
Aturan tentang hak nâzhir ini adalah sebuah tantangan bagi nâzhir profesional yang memiliki kemampuan manajerial tinggi. Saat ini profesi nâzhir masih dipandang sebelah mata. Seiring dengan waktu, profesi nâzhir menjadi sebuah profesi menjanjikan yang sederajat dengan profesi populer lainnya.

\section{PP 42/2006}

PP 42/2006 terlihat memposisikan nâzhir sebagai pembahasan utama. Tidak kurang dari 13 pasal secara berurutan mulai pasal 2 sampai pasal 14 menejlaskan tentang jenis nâzhir, tugas dan kewajiban nâzhir, serta yang paling penting adalah masa bakti nâzhir.

Pasal 2 menjelaskan jenis nâzhir yang terdiri dari nâzhir perseorangan, organisasi, dan badan hukum. Pasal 4 menjelaskan natara lain tentang jumlah nâzhir perseorangan yang terdiri minamla 3 orang dan salah satunya harus bertempat tinggal di kecamatan tempat benda wakaf berada. Selanjutnya Pasal 5 menjelaskan berhentinya satus nâzhir dengan alasan: a) a. meninggal dunia; b) berhalangan tetap; c) mengundurkan diri; atau d) diberhentikan oleh BWI.

Adapun nâzhir Organisasi dijelaskan dalam Pasal 7. Pasal ini menegaskan bahwa nâzhir organisasi wajib didaftarkan pada Menteri dan BWI melalui Kantor Urusan Agama setempat. Nâzhir organisasi merupakan organisasi yang bergerak di bidang sosial, pendidikan, kemasyarakatan dan/atau keagamaan Islam yang memenuhi persyaratan sebagai berikut: a) pengurus organisasi harus memenuhi persyaratan Nâzhir perseorangan; b) salah seorang pengurus organisasi harus berdomisili di kabupaten/kota letak benda wakaf berada; c) memiliki: 1) salinan akta notaris tentang pendirian dan anggaran dasar; 2) daftar susunan pengurus; 3) anggaran rumah tangga; 4) program kerja dalam pengembangan wakaf; 5) daftar kekayaan yang berasal dari harta wakaf yang terpisah dari kekayaan lain atau yang merupakan kekayaan organisasi; dan 6) surat pernyataan bersedia untuk diaudit.

Pasal 11 menjelaskan tentang Nâzhir Badan Hukum. Nâzhir badan hukum wajib didaftarkan pada Menteri dan BWI melalui Kantor Urusan Agama setempat. Nâzhir badan hukum yang melaksanakan pendaftaran sebagaimana dimaksud pada ayat (1) harus memenuhi persyaratan: a) badan hukum Indonesia yang bergerak di bidang sosial, pendidikan, kemasyarakatan, dan/atau keagamaan Islam; b) pengurus badan hukum harus memenuhi persyaratan Nâzhir perseorangan; c) salah seorang pengurus badan hukum harus berdomisili di kabupaten/kota benda wakaf berada; d) memiliki: 1) salinan akta notaris tentang pendirian dan anggaran dasar badan hukum yang telah disahkan oleh instansi berwenang; 2) daftar susunan pengurus; 3) anggaran rumah tangga; 4) program kerja dalam pengembangan wakaf; 5) daftar terpisah kekayaan yang berasal dari harta benda wakaf atau yang merupakan kekayaan badan hukum; dan 6) surat pernyataan bersedia untuk diaudit.

Pasal 14 menjelaskan masa bakti Nâzhir yang dibatasi hanya 5 (lima) tahun dan dapat diangkat kembali. Pengangkatan kembali Nâzhir dilakukan oleh BWI, apabila yang bersangkutan telah melaksanakan tugasnya dengan baik dalam periode sebelumnya sesuai ketentuan prinsip syariah dan Peraturan Perundang-undangan.

\section{Konsep Sanksi Pidana}

\section{UU No 5/1960}

Tidak ada ketentuan pidana dalam UU No 5 Tahun 1960, khususnya tentang wakaf. Aturan pidana yang ada adalah pasal 52 tentang pidana untuk orang yang melanggar pasal 15. Pasal 15 itu berbunyi:
Memelihara tanah, termasuk menambah kesuburannya serta mencegah kerusakannya adalah kewajiban tiap-tiap orang, badan hukum atau instansi yang mempunyai hubungan hukum dengan tanah itu, dengan memperhatikan pihak yang ekonomis lemah.

Adapun pasal 52 berbunyi:
(1) Barang siapa dengan sengaja melanggar ketentuan dalam pasal 15 dipidana dengan hukuman kurungan selama-lamanya 3 bulan dan/atau denda setinggi-tingginya $R p$. 10.000,-.
(2) Peraturan Pemerintah dan peraturan perundangan yang dimaksud dalam pasal 19, 22, 24, 26 ayat 1, 46, 47, 48, 49 ayat 3 dan 50 ayat 2 dapat memberikan ancaman pidana atas


pelanggaran peraturannya dengan hukuman kurungan selama-lamanya 3 bulan dan/atau denda setinggitingginya Rp. 10.000,-.

(3) Tindak pidana dalam ayat 1 dan 2 pasal ini adalah pelanggaran.

Dari kedua pasal di atas, terlihat jelas bahwa aturan pidana itu bukna untuk wakaf. Ketentuan pidana itu diperuntukkan bagi mereka yang melakukan pengrusakan dan penghancuran lingkungan, khususnya berkaitan dengan tanah. Ancamannya adalah penjara 3 bulan atau denda 10.000,--

\section{PP 28/1977}

Ketentuan pidana sudah diatur dalam PP 28/1977 pasal 14-15. Pasal 14 berbunyi:

Barangsiapa melakukan perbuatan yang melanggar ketentuan-ketentuan sebagaimana dimaksud pasal 5, pasal 6 ayat (3), pasal 7 ayat (1) dan ayat (2), pasal 9, pasal 10 dan pasal 11, dihukum dengan hukuman kurungan selamalamanya 3 (tiga) bulan atau denda sebanyak-banyaknya Rp. 10.000,(sepuluh ribu rupiah).

Adapun Pasal 15 berbunyi:

Apabila perbuatan yang dimaksud dalam pasal 14 dilakukan oleh atau atas nama badan hukum maka tuntutan pidana dilakukan dan pidana serta tindakan tata tertib dijatuhkan, baik terhadap badan hukum maupun terhadap mereka yang memberi perintah melakukan perbuatan tersebut atau yang bertindak sebagai pemimpin atau penanggung jawab dalam perbuatan atau kelalaian itu atau terhadap kedua-duanya.

Ketentuan pidana dalam PP ini dikaitkan dengan pasal 5, pasal 6 ayat (3), pasal 7 ayat (1) dan ayat (2), pasal 9, pasal 10 dan pasal 11. Pasal 5 berisi tentang keharusan mengikrarkan kehendaknya secara jelas dan tegas kepada Nâdzir di hadapan Pejabat Pembuat Akta Ikrar Wakaf. Pasal 6 (3) keharusan nâdzir didaftar pada Kantor Urusan Agama Kecamatan setempat untuk mendapatkan pengesahan. Pasal 7 berisi tentang kewajiban nâzhir. Pasal 9 tentang tatacara perwakafan tanah milik, pasal 10 tentang pendaftaran perwakafan tanah milik, dan pasal 11 tentang perubahan perwakafan tanah milik. Dengan demikian, ancaman pidana dalam PP ini dikhususkan bagi pengelola wakaf agar berhati-hati dalam menjaga, mengelola, dan mengawasi harta benda wakaf.

\section{KHI}

Tidak ada ketentuan pidana dalam Kompilasi Hukum Islam.

\section{UU 41/2004}

UU ini menegaskan tentang ketentuan pidana wakaf dalam satu pasal, yakni pasal 67 . Bunyi pasal ini adalah sebagai berikut: (1) Setiap orang yang dengan sengaja menjaminkan, menghibahkan, menjual, mewariskan, mengalihkan dalam bentuk pengalihan hak lainnya harta benda wakaf yang telah diwakafkan sebagaimana dimaksud dalam Pasal 40 atau tanpa izin menukar harta benda wakaf yang telah diwakafkan sebagaimana dimaksud dalam Pasal 41, dipidana dengan pidana penjara paling lama 5 (lima) tahun dan/atau pidana denda paling banyak Rp 500.000.000,00 (lima ratus juta rupiah); (2) Setiap orang yang dengan sengaja mengubah peruntukan harta benda wakaf tanpa izin sebagaimana dimaksud dalam Pasal 44, dipidana dengan pidana penjara paling lama 4 (empat) tahun dan/atau pidana denda paling banyak $\mathrm{Rp}$ 400.000.000,00 (empat ratus juta rupiah); (3) Setiap orang yang dengan sengaja menggunakan atau mengambil fasilitas atas hasil pengelolaan dan pengembangan harta benda wakaf melebihi jumlah yang ditentukan sebagaimana dimaksud dalam Pasal 12, dipidana dengan pidana penjara paling lama 3(tiga) tahun dan/atau pidana denda paling banyak Rp 300.000.000,00 (tiga ratus juta rupiah).

Pasal ini memberikan tiga kategori pidana dalam wakaf. Pertama adalah pelanggaran berat, yakni sengaja menjaminkan, menghibahkan, menjual, mewariskan, mengalihkan dalam bentuk pengalihan hak lainnya. Ancamannya adalah pidana penjara paling lama 5 (lima) tahun dan/atau pidana denda paling banyak Rp 500.000.000,00 (lima ratus juta rupiah). Kedua adalah pelanggaran sedang, yaitu sengaja mengubah peruntukan harta benda wakaf tanpa izin. Ancamannya adalah pidana penjara paling lama 4 (empat) tahun dan/atau pidana denda paling banyak Rp 
400.000.000,00 (empat ratus juta rupiah). Adapun pelanggaran yang ketiga adalah pelanggaran ringan, yaitu sengaja menggunakan atau mengambil fasilitas atas hasil pengelolaan dan pengembangan harta benda wakaf melebihi jumlah yang ditentukan. Ancamannya adalah pidana penjara paling lama 3(tiga) tahun dan/atau pidana denda paling banyak Rp 300.000.000,00 (tiga ratus juta rupiah).

Dari uraian di atas dapat disimpulkan bahwa UU 41/2004 ini mempunyai semangat untuk menertibkan pengelolaan wakaf secara profesional. Ancaman pidana maupun denda diharapkan akan mendorong para nâzhir wakaf untuk berhati-hati dalam pengelolaan wakaf. Dengan demikian, harta benda wakaf akan terjaga keabadian manfaatnya sesuai dengan niat wâkif.

\section{PP 42/2006}

Tidak ada aturan tentang hukuman pidana dalam PP 42/2006. Hal ini bisa jadi karena PP ini bersifat menjelaskan hal-hal yang belum disinggung dalam UU. Meskipun begitu, PP ini memuat sanksi administratif bagi LKS-PWU yang tidak melakukan tugasnya dengan baik yang termaktub dalam Pasal 57. Bunyi pasal 57 adalah sebagai berikut: 1) Menteri dapat memberikan peringatan tertulis kepada LKS-PWU yang tidak menjalankan kewajiban sebagaimana dimaksud dalam Pasal 25; 2) Peringatan tertulis paling banyak diberikan 3 (tiga) kali untuk 3 (tiga) kali kejadian yang berbeda; 3) Penghentian sementara atau pencabutan izin sebagai LKSPWU dapat dilakukan setelah LKS-PWU dimaksud telah menerima 3 kali surat peringatan tertulis; 4) Penghentian sementara atau pencabutan izin sebagai LKS-PWU dapat dilakukan setelah mendengar pembelaan dari LKS-PWU dimaksud dan/atau rekomendasi dari instansi terkait.

Secara garis besar perbandingan tiga konsep: wakaf, nâzhir, dan ketentuan pidana dalam UU 5/1960, PP 28/1977, KHI, UU 41/2004, dan PP 42/2006 dapat dicermati dalam tabel berikut.

Tabel Perbandingan Konsep Wakaf, Nâzhir, dan Pidana

\begin{tabular}{|c|c|c|c|c|c|}
\hline & UU 5/1960 & PP 28/1977 & KHI & UU 41/2004 & PP 42/2006 \\
\hline $\begin{array}{l}\text { Konsep } \\
\text { wakaf }\end{array}$ & $\begin{array}{l}\text { Wakaf perlu } \\
\text { PP }\end{array}$ & $\begin{array}{l}\text { Hanya } \\
\text { wakaf tanah } \\
\text { milik untuk } \\
\text { selamanya }\end{array}$ & $\begin{array}{lr}\text { Wakaf } & \text { benda } \\
\text { bergerak } & \text { dan } \\
\text { wakaf } & \text { tidak } \\
\text { bergerak } & \text { untuk } \\
\text { selamanya } & \\
\end{array}$ & $\begin{array}{l}\text { Benda } \\
\text { bergerak-tak } \\
\text { bergerak } \\
\text { Wakaf } \\
\text { berjangka }\end{array}$ & $\begin{array}{l}\text { Sama dengan } \\
\text { UU 41/2004 }\end{array}$ \\
\hline $\begin{array}{l}\text { Konsep } \\
\text { Nâzhir }\end{array}$ & Tidak ada & $\begin{array}{l}\text { nâzhir } \\
\text { perorangan } \\
\text { dan badan } \\
\text { hukum; } \\
\text { berhak } \\
\text { mendapat } \\
\text { penghasilan } \\
\text { namun } \\
\text { tidak jelas }\end{array}$ & $\begin{array}{ll}\text { mempertegas } & \\
\text { konsep } & \text { PP } \\
28 / 1977 & \end{array}$ & $\begin{array}{l}\text { nâzhir } \\
\text { perorangan, } \\
\text { organisasi, dan } \\
\text { badan hukum; } \\
\text { berinduk pada } \\
\text { Badan Wakaf } \\
\text { Indonesia; } \\
\text { berpenghasilan } \\
10 \% \text { dari hasil } \\
\text { bersih } \\
\text { pengelolaan } \\
\text { aset wakaf }\end{array}$ & $\begin{array}{l}\text { menguatkan } \\
\text { UU No } \\
41 / 2004 ; \\
\text { menjelaskan } \\
\text { masa bakti } \\
\text { nâzhir } 5 \text { tahun } \\
\text { dan dapat } \\
\text { diangkat } \\
\text { kembali }\end{array}$ \\
\hline $\begin{array}{l}\text { Ketentuan } \\
\text { Pidana }\end{array}$ & $\begin{array}{l}\text { penjara } 3 \\
\text { bulan, denda } \\
\text { Rp. } 10.000\end{array}$ & $\begin{array}{l}\text { penjara } 3 \\
\text { bulan, } \\
\text { denda } \\
10.000\end{array}$ & Tidak ada & $\begin{array}{l}\text { Maks } 5 \text { tahun } \\
\text { penjara/ Rp.500 } \\
\text { juta, min } 3 \\
\text { tahun /Rp.300 } \\
\text { juta }\end{array}$ & $\begin{array}{l}\text { Hanya sanksi } \\
\text { administratif }\end{array}$ \\
\hline
\end{tabular}

Dari tabel di atas dapat diketahui bahwa dalam hal konsep wakaf, UU 5/1960 telah memberikan peluang terjadinya wakaf di Indonesia meskipun masih membutuhkan PP. Setelah 17 tahun, PP yang ditunggu-tunggu 
disahkan. Dalam PP 28/1977 tersebut, konsep wakaf lebih detail meskipun masih sederhana yang kemudian dikuatkan dengan hadirnya KHI. Puncak konsep wakaf dapat dilihat dalam UU 41/2004 yang dilengkapi dengan PP 42/2006.

Dalam hal wâkif dan nâzhir, konsep awal sudah diperkenalkan dalam PP 28/1977 dan dikuatkan oleh KHI. Namun, versi terbaru telah disebutkan dalam UU 41/2004 dan PP 42/2006. Salah satu hal baru yang disebutkan UU 41/2004 dan PP 42/2006 adalah adanya wâkif dan nâzhir organisasi. Selain itu, aturan tentang nâzhir dalam UU 41/2004 dan PP 42/2006 lebih nyata. Di antaranya adalah hak nâzhir sebesar $10 \%$ dari hasil kelola wakaf dan masa bakti nâzhir yang dibatasi hanya 5 tahun yang kemudian dapat diperpanjang.

Terakhir, aturan pidana dari waktu ke waktu mengalami perubahan. Jika dalam UU 5/1960 dan PP 28/1977 ancaman pidana kurungan hanya 3 bulan dan ancaman denda maksimal Rp.10.000, maka dalam UU 41/2004 ketentuan pidana lebih jelas, yakni kurungan maksimal 5 tahun dan denda maksimal Rp. 500 juta. Ini menunjukkan bahwa persoalan wakaf yang berpeluang untuk diselewengkan mendapat perhatian khusus dalam regulasi wakaf di Indonesia.

\section{Regulasi Wakaf Ditinjau dari Statute Approach}

Regulasi wakaf sejak pasca kemerdekaan hingga era reformasi dapat ditinjau dari sisi pendekatan perundang-undangan. Pendekatan yang digunakan adalah pendekatan perundangundangan yang disampaikan Peter Mahmud Marzuki dalam bukunya "Penelitian Hukum". Dalam buku tersebut sebagaimana telah diuraikan secara luas pada bab II, Marzuki menyebut tiga asas hukum yang dapat digunakan sebagai pisau analisis, yakni Asas Lex Superior Derogat Legi Inferiori, asas Lex Specialis Derogat Legi Generali, dan asas Lex Posterior Derogat Legi Priori. Berikut ini diuraikan tentang penggunaan ketiga asas tersebut untuk melihat regulasi wakaf di Indonesia.

Asas Lex Superior Derogat Legi Inferiori. Asas ini menyatakan bahwa aturan hukum yang lebih tinggi mengganti aturan hukum yang lebih rendah. Jika asas ini diterapkan
Sudirman, Regulasi Wakaf di Indonesia...| 201

dalam regulasi wakaf di Indonesia pasca kemerdekaan, dapat disimpulkan bahwa segala aturan wakaf yang memiliki posisi tinggi harus menggantikan segala aturan wakaf yang lebih rendah. Dengan demikian, aturan wakaf yang tercantum dalam UU 5/1960 yang kemudian dikuatkan oleh UU 41/2004 harus diutamakan ketimbang aturan-aturan di bawahnya. UU 5/1960 telah dikuatkan oleh PP 28/1977 sedangkan UU 41/2004 telah mempunyai penjelasan lengkap dalam PP 42/2006. Oleh sebab itu, kandungan dalam PP 28/1977 dan PP 42/2006 harus sejalan dengan isi dalam UU 5/1960 dan UU 41/2004.

Asas Lex Specialis Derogat Legi Generali. Asas ini menegaskan bahwa aturan hukum yang khusus mengganti aturan hukum yang lebih umum. Dalam konteks regulasi wakaf di Indonesia, aturan wakaf yang khusus menggantikan aturan wakaf yang umum. Jika asas ini diterapkan dalam konteks undangundang, maka UU 41/2004 merupakan regulasi spesifik yang mengatur wakaf. UU 41/2004 ini menggantikan aturan-aturan wakaf sebelumnya, misalnya UU 5/1960 yang menyebut wakaf tanah milik sebagai bagian dari peribadatan seseorang. Selain itu, aturanaturan wakaf yang sebetulnya berstatus di bawah undang-undang, seperti PP 28/1977 dan $\mathrm{KHI}$, secara otomatis dinyatakan tidak berlaku.

Asas Lex Posterior Derogat Legi Priori, maksud asas ini adalah bahwa aturan hukum yang baru menggantikan aturan hukum yang lebih lama. Dalam konteks wakaf, aturan wakaf yang termaktub dalam UU 41/2004 menggantikan aturan wakaf yang ada pada periode sebelumnya, seperti UU 5/1960, PP 28/1977 dan KHI. Adapun PP 42/2006 yang merupakan penjelasan dari UU 41/2004 tetap dianggap sebagai bagian dari UU 41/2004. Jadi, aturan wakaf yang utama merujuk pada UU 41/2004 dan PP 42/2006.

Dari paparan di atas dapat disimpulkan bahwa peraturan yang memiliki status sederajat adalah UU 5/1960 dan UU 41/2004. Selain itu, ditingkat PP, status sederajat adalah PP 28/1977 dan PP 42/2006. Namun, jika dilihat secara utuh, UU 41/2004 menjadi aturan wakaf paling mutakhir dan puncak regulasi wakaf di Indonesia. UU 41/2004 ini menjadi lebih lengkap setelah dikeluarkannya PP 42/2006. Adapun aturan wakaf yang paling rendah 
adalah KHI. Hal ini dapat dimaklumi karena KHI hanya didukung oleh Instruksi Presiden Nomor 1 Tahun 1991.

\section{Kesimpulan}

Dari pembahasan dalam bab-bab sebelumnya dapat disimpulkan bahwa latar belakang munculnya berbagai peraturan wakaf di Indonesia pasca kemerdekaan sarat dengan tuntutan perlunya regulasi khusus yang mengatur tentang wakaf serta reaksi dari perkembangan hukum wakaf kontemporer. Kalau UU 5/1960 adalah tonggak awal persoalan wakaf disentuh dalam regulasi Indonesia sekelas undang-undang, maka UU 41/2004 dapat dikatakan sebagai jawaban puncak atas kegelisahan regulasi wakaf di Indonesia yang harus mampu menjawab tantangan zaman seperti tentang wakaf uang dan wakaf berjangka. Kemudian, perbandingan regulasi wakaf pasca kemerdekaan hingga era reformasi dapat disimpulkan bahwa dalam hal konsep wakaf, UU 5/1960 telah memberikan peluang terjadinya wakaf di Indonesia. Puncak konsep wakaf dapat dilihat dalam UU 41/2004 yang dilengkapi dengan PP 42/2006. Dalam hal wâkif dan nâzhir, konsep awal sudah diperkenalkan dalam PP 28/1977 dan dikuatkan oleh KHI. Namun, versi terbaru telah disebutkan dalam UU 41/2004 dan PP 42/2006, seperti adanya wâkif dan nâzhir organisasi. Lebih lanjut, konsep harta wakaf mengalami perubahan signifikan. Jika dalam PP 28/1977 harta wakaf terbatas hanya tanah milik, UU 41/2004 dan PP 42/2006 memberikan keluasan jenis benda wakaf yang terdiri dari benda tidak bergerak, benda bergerak berupa uang, dan

\section{DAFTAR PUSTAKA}

Departemen Agama, 2006, Al-Qur'an dan Terjemahnya, Surabaya: Pustaka Agung Harapan.

Djunaidi, Achmad, dkk., 2006, Perkembangan Pengelolaan Wakaf di Indonesia, Jakarta: Direktorat Pemberdayaan Wakaf.

Hafidhuddin, Didin, 2007, Agar Harta Berkah dan Bertambah, Jakarta: Gema Insani Press, Jakarta.

al-Hafsakî, Alauddin Muhammad bin 'Alî, t.th., ad-Dur al-Mukhtâr, t.tp.: t.p. benda bergerak selain uang. Ini merupakan terobosan signifikan dalam sejarah wakaf di Indonesia. Terakhir, aturan pidana dari waktu ke waktu mengalami perubahan. Jika dalam UU 5/1960 dan PP 28/1977 ancaman pidana kurungan hanya 3 bulan dan ancaman denda maksimal Rp.10.000, maka dalam UU 41/2004 ketentuan pidana lebih jelas, yakni kurungan maksimal 5 tahun dan denda maksimal Rp. 500 juta.

Perbandingan Regulasi ditinjau dari Statute Approach dapat dianalisis dengan menggunakan tiga asas hukum. Pertama, asas Lex Superior Derogat Legi Inferiori menyimpulkan bahwa segala aturan wakaf yang memiliki posisi tinggi harus menggantikan segala aturan wakaf yang lebih rendah. Dengan demikian, aturan wakaf yang tercantum dalam UU 5/1960 yang kemudian dikuatkan oleh UU 41/2004 harus diutamakan ketimbang aturan-aturan di bawahnya. Kedua, asas Lex Specialis Derogat Legi Generali menegaskan bahwa UU 41/2004 merupakan regulasi spesifik yang mengatur wakaf. UU 41/2004 ini menggantikan aturan-aturan wakaf sebelumnya, misalnya UU 5/1960 yang menyebut wakaf tanah milik sebagai bagian dari peribadatan seseorang. Ketiga, asas Lex Posterior Derogat Legi Priori meniscayakan bahwa aturan wakaf yang termaktub dalam UU 41/2004 menggantikan aturan wakaf yang ada pada periode sebelumnya, seperti UU 5/1960, PP 28/1977 dan KHI. Jadi, aturan wakaf yang utama merujuk pada UU 41/2004 dan PP 42/2006.

al-Kabisi, Muhammad Abid Abdullah, 2004, Hukum Wakaf, diterjemahkan oleh Ahrul Sani Fathurrohman (et.al.), Jakarta, IIMaN Press.

Marzuki, Peter Mahmud, Penelitian Hukum, Jakarta: Prenada Media Group, 2010.

an-Naisâburî, Muslim bin Hajjâj, t.th., Sahîh Muslim, Kairo: Mauqi' Wizârah alAuqaf al-Misriyyah.

Qardhawi, Yusuf, 1997, Fiqh az-Zakat, Jilid I, Beirut: Muassasah ar-Risalah.

ibn Qudâmah, 'Abd ar-Rahmân bin Abû 'Umar, t.th., asy-Syarh al-Kabîr, t.tp.: t.p. 
Sudirman, Regulasi Wakaf di Indonesia...| 203

Suyono, Yusuf, dkk., 2007, Wakaf Produktif di Indonesia, Studi atas Pengelolaan Aset Wakaf Pondok Modern Gontor Ponorogo 1958-2006, Semarang: IAIN Walisongo.

Syaukani, Imam, 2006, "Pemberdayaan Pengelolaan Wakaf Rumah Sakit Islam Sunan Kudus Kabupaten Kudus", dalam Muchit A. Karim dkk., Pengelolaan Wakaf dan Pemberdayaan di Indonesia, Jakarta: Puslitbang Kehidupan Keagamaan.
Tulus dkk., 2005, Nazhir Profesional dan Amanah, Jakarta: Direktorat Pengembangan Zakat dan Wakaf.

at-Turmudzî, Muhammad bin 'Îsâ, t.th., Sunan at-Turmudzî, Kairo: Mauqi' Wizârah al-Auqâf al-Mishriyyah.

Warson, Ahmad, 1984, al-Munawwir, Kamus ArabIndonesia, t.tp.: t.p.

Wehr, Hans, 1994, Arabic-English Dictionary, the Hans Wehr Dictionary of Modern Written Arabic, Urbana: Spoken Language Services.

az-Zuhailî, Wahbah, t.th., al-Fiqh al-Islâmî wa Adillatuh, Beirut: Dâr al-Fikr. 